\title{
Bioactive Diarylheptanoids from Alpinia coriandriodora
}

\author{
Xiao-Li Cheng ${ }^{1,3} \cdot$ Han-Xiang $\mathrm{Li}^{1,2} \cdot$ Juan Chen ${ }^{1,2} \cdot$ Ping Wu $^{1,2,3} \cdot$ Jing-Hua Xue ${ }^{1,2} \cdot$ Zhong-Yu Zhou $^{1,2,3} \cdot$ Nia-He Xia ${ }^{1,2,3}$. \\ Xiao-Yi Wei ${ }^{1,2,3}$ (1)
}

Received: 14 August 2020 / Accepted: 30 August 2020 / Published online: 9 September 2020

(C) The Author(s) 2020

\begin{abstract}
Eight new diarylheptanoids, coriandralpinins A-H (1-8), were isolated from the rhizomes of Alpinia coriandriodora, an edible plant of the ginger family. Their structures, including the absolute configurations, were established by extensive spectroscopic analysis and ECD calculations. Compounds 1-8 have a 1,5- $O$-bridged diarylheptanoid structure featuring polyoxygenated aryl units. When evaluated for intracellular antioxidant activity using $t$-BHP stressed RAW264.7 macrophages, all these compounds scavenged reactive oxygen species (ROS) in a concentration-dependent manner. Compounds 3 and $\mathbf{5}$ also showed inhibitory activity against NO release in LPS-induced RAW 264.7 cells. Six known flavonols, 7,4'-di$O$-methylkaempferol, 7- $O$-methylquercetin, 7,4'-di- $O$-methylquercetin, 7, $3^{\prime}, 4^{\prime}$-tri- $O$ - methylquercetin, kaempferol 3- $O$ - $\beta$-D(6- $O$ - $\alpha$-L-rhamnopyranosyl)glucopyranoside, and 3-O- $\beta$-D-glucopyranuronosylquercetin were also isolated and characterized from the rhizomes.
\end{abstract}

Keywords Alpinia coriandriodora $\cdot$ Diarylheptanoid $\cdot$ Antioxidant $\cdot$ Anti-inflammatory

\section{Introduction}

Metabolism of oxygen is crucial to life for the production of energy to support biological process. As a consequence of the aerobic metabolism, reactive oxygen species (ROS) are continuously generated in all living organisms,

Xiao-Li Cheng, Han-Xiang Li, and Juan Chen have contributed equally to this work.

Electronic supplementary material The online version of this article (https://doi.org/10.1007/s13659-020-00264-y) contains supplementary material, which is available to authorized users.

Xiao-Yi Wei

wxy@scbg.ac.cn

1 Key Laboratory of Plant Resources Conservation and Sustainable Utilization, South China Botanical Garden, Chinese Academy of Sciences, Tianhe District, Xingke Road 723, Guangzhou 510650, People's Republic of China

2 Guangdong Provincial Key Laboratory of Digital Botanical Garden, South China Botanical Garden, Chinese Academy of Sciences, Xingke Road 723, Tianhe District, Guangzhou 510650, People's Republic of China

3 School of Life Sciences, University of Chinese Academy of Sciences, Yuquanlu 19A, Beijing 100049, People's Republic of China and controlled by several antioxidant mechanisms [1, 2]. However, overproduction and/or mismanagement of ROS may evade cellular antioxidant defense systems, resulting in the general phenomenon of oxidative stress. The redox imbalance leads to cellular damage, which is implicated with inflammatory process and various chronic degeneration diseases such as cancer, cardiovascular disease and diabetes [3-6]. In recent years there has been increasing interest in antioxidants of plant origin [7-10], particularly those from edible plants, and many of these naturally occurring compounds have been shown to possess protective efficacies against oxidative stress and inflammation-related diseases [11-14].

As part of our going effort to isolate and identify antioxidant and anti-inflammatory compounds from edible and medicinal plants, our attention was drawn to Alpinia coriandriodora D. Fang (Zigiberaceae), a perennial herb distributed in Guangxi, China. Plants of the genus Alpinia are rich in diarylheptanoids, sesquiterpenoids, and monoterpenes, many of which possess antioxidant $[15,16]$, anti-inflammatory [17], hepatoprotective [18], and anticancer activities $[19,20]$. Although A. coriandriodora has long been used by local inhabitants as food spices, few chemical investigations on the species have been reported so far. We now present herein the isolation, characterization, and biological 
activities of eight new diarylheptanoids, coriandralpinins A-G (1-8) (Fig. 1), from the rhizomes of this plant. The isolation of six known flavonoids is also described.

\section{Results and Discussion}

The powder of dry A. coriandriodora rhizomes was extracted with EtOH. The crude extract was suspended in water and extracted successively with petroleum ether, EtOAc, and $n-\mathrm{BuOH}$. The resultant three fractions were separately subjected to column chromatography over silica gel, ODS, and Sephadex LH-20, followed by semi-preparative HPLC, to afford new diarylheptanoids 1-8 (Fig. 1) and known flavonols 9-14 (Fig. S1, Supplementary Material).

Coriandralpinin A (1) was obtained as light brown oil. Its HRESIMS showed a pseudo-molecular ion at $\mathrm{m} / \mathrm{z} 435.2009$ $\left([\mathrm{M}+\mathrm{H}]^{+}\right)$, indicating the molecular formula $\mathrm{C}_{23} \mathrm{H}_{30} \mathrm{O}_{8}$. The ${ }^{13} \mathrm{C}$ NMR spectrum contained signals for 23 carbons including twelve aromatic (four methine and eight nonprotonated), four methoxy, four aliphatic methylene, and three aliphatic methine carbons. Combined analysis of the

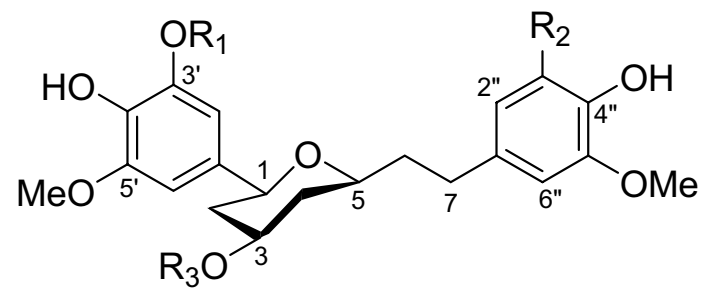

$1 \mathrm{R}_{1}=\mathrm{Me}, \mathrm{R}_{2}=\mathrm{OMe}, \mathrm{R}_{3}=\mathrm{H}$

$2 \mathrm{R}_{1}=\mathrm{Me}, \mathrm{R}_{2}=\mathrm{R}_{3}=\mathrm{H}$

$3 \mathrm{R}_{1}=\mathrm{R}_{2}=\mathrm{R}_{3}=\mathrm{H}$

$4 \mathrm{R}_{1}=\mathrm{R}_{3}=\mathrm{H}, \mathrm{R}_{2}=\mathrm{OMe}$

$5 \mathrm{R}_{1}=\mathrm{Me}, \mathrm{R}_{2}=\mathrm{OMe}, \mathrm{R}_{3}=\mathrm{Ac}$
${ }^{1} \mathrm{H}$ and ${ }^{13} \mathrm{C}$ NMR data (Tables 1 and 2) with COSY and HSQC spectra revealed the presence of two 3,5-dimethoxy4-hydroxyphenyl moieties [ $\delta_{\mathrm{H}} 6.41,6.63$ (each $2 \mathrm{H}, \mathrm{s}$ ), 3.84, $3.90($ each $\left.6 \mathrm{H}, \mathrm{s}) ; \delta_{\mathrm{C}} 103.0,105.2,56.4,56.5\right]$ and a seven membered aliphatic chain (Fig. 2). In the HMBC spectrum (Fig. 2), correlations of $\mathrm{H}-1$ with $\mathrm{C}-1^{\prime},-2^{\prime}$, and $-6^{\prime}$ and of $\mathrm{H}_{2}-7$ with $\mathrm{C}-1$ ", $-2^{\prime \prime}$, and -6 " suggested that the two phenyl rings were connected to the alkyl chain terminal carbons $\mathrm{C}-1$ and $\mathrm{C}-7$, respectively. In addition, correlations of $\mathrm{H}-1 / \mathrm{C}-5$ and $\mathrm{H}-5 / \mathrm{C}-1$ indicated that $\mathrm{C}-1$ was linked to $\mathrm{C}-5$ via an oxygen atom to form a tetrahydropyran unit. The relative stereochemistry of $\mathbf{1}$ was elucidated on the basis of proton coupling constants and NOESY correlations. In the ${ }^{1} \mathrm{H}$ NMR spectrum, $\mathrm{H}-1\left(\delta_{\mathrm{H}} 4.26\right)$ and $\mathrm{H}-2 \mathrm{ax}\left(\delta_{\mathrm{H}} 1.50\right)$ appeared as a double doublet $(J=11.4,2.0 \mathrm{~Hz})$ and an apparent quartet $(J=11.4 \mathrm{~Hz})$, respectively, suggesting that $\mathrm{H}-1$ and $\mathrm{H}-3\left(\delta_{\mathrm{H}}\right.$ 3.94) are both in axial positions. The remaining oxymethine proton $\mathrm{H}-5$ was also assigned to be axial by the NOE interactions observed for $\mathrm{H}-5 / \mathrm{H}-1$ and $\mathrm{H}-5 / \mathrm{H}-3$ (Fig. 2). Based on the established relative configuration, the absolute configuration of $\mathbf{1}$ was assigned by electronic circular dichroism (ECD) spectrum aided with ECD/TDDFT calculations. The

Fig. 1 Structures of coriandralpinins A-G (1-8)

Fig. 2 COSY (bold lines) and key HMBC (arrows) and NOESY (dashed arrows) correlations of 1 (the 3D conformer represents the DFT global energy minimum)
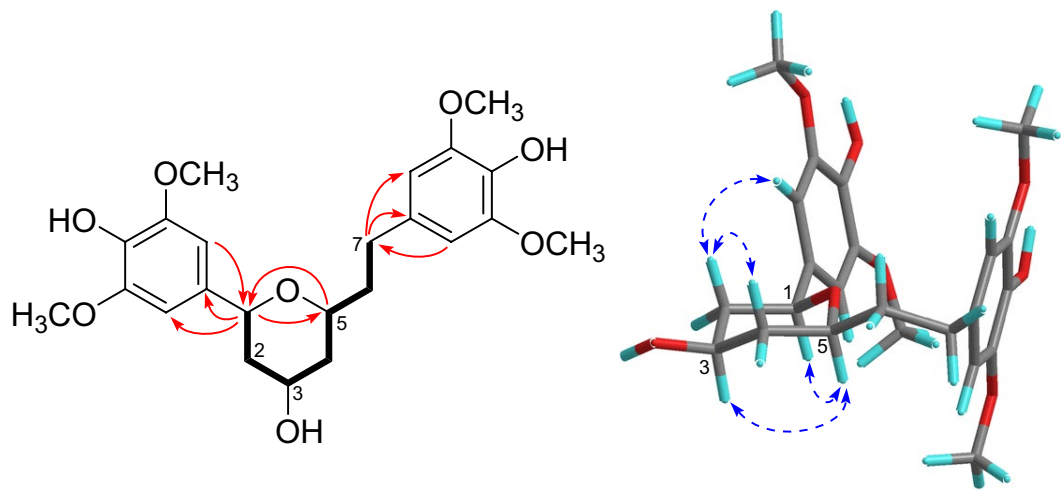


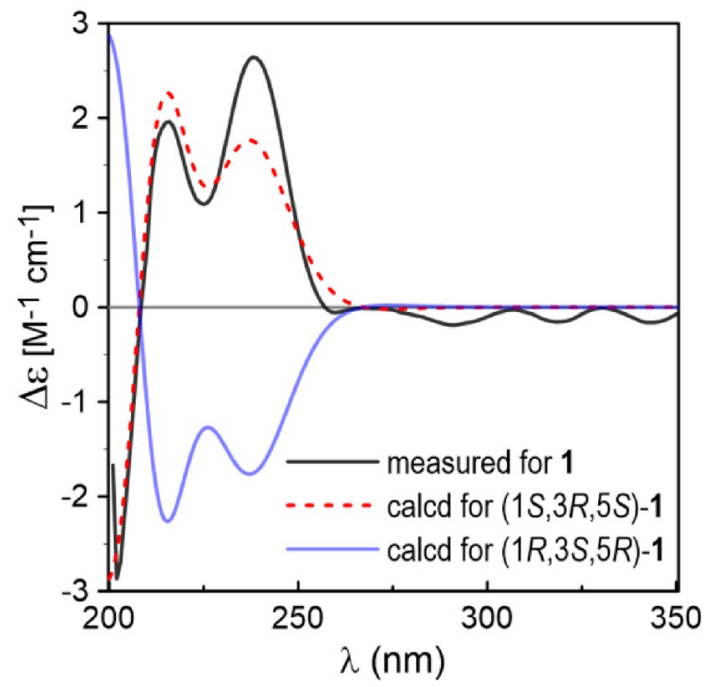

Fig. 3 Comparison between the measured and PBE0/Def2-SVP/PCM $(\mathrm{MeOH})$ calculated ECD spectra of $\mathbf{1}(\sigma=0.34$, shift $=+11 \mathrm{~nm})$

experimental ECD spectrum of $\mathbf{1}$ exhibited positive Cotton effects at 242 and $216 \mathrm{~nm}$, which matched well with those of the theoretical spectrum calculated for the $1 S, 3 R, 5 S$ isomer (Fig. 3). On the basis of the above analysis, the structure of 1 was established as $(1 S, 3 R, 5 S)$-1,5-epoxy-1,7-bis(4-hydroxy3,5-dimethoxyphenyl)heptan-3-ol.

Coriandralpinins B-E (2-5) were elucidated to have diarylheptanoid structures closely related to coriandralpinin A (1) on the basis of their UV, NMR (Tables 1 and 2), and HRESIMS data. Compound $\mathbf{2}$ was determined to have a molecular formula containing one $\mathrm{CH}_{2} \mathrm{O}$ unit less than 1. It differed from 1 in that the 3,5-dimethoxy-4-hydroxyphenyl group at C-7 in 1 was replaced by a 4-hydroxy-3-methoxyphenyl group as indicated by an $\mathrm{ABX}$ spin system at $\delta_{\mathrm{H}}$ $6.82(1 \mathrm{H}, \mathrm{d}, J=8.0 \mathrm{~Hz}), 6.68(1 \mathrm{H}, \mathrm{dd}, J=8.0,1.9 \mathrm{~Hz})$, and $6.69(1 \mathrm{H}, \mathrm{d}, J=1.9 \mathrm{~Hz})$ for three aromatic protons and a $3 \mathrm{H}$ singlet at $\delta_{\mathrm{H}} 3.83$ for an aromatic methoxy in the ${ }^{1} \mathrm{H}$ NMR spectrum. Compounds 3 had a molecular formula with one $\mathrm{CH}_{2}$ unit less than 2. Its ${ }^{1} \mathrm{H}$ NMR spectrum was closely similar to that of $\mathbf{2}$ except that signals for the $\mathrm{C}-1$ aryl group appeared as two meta-coupled doublets at $\delta_{\mathrm{H}} 6.54$ and 6.53 (each $1 \mathrm{H}, J=2.0 \mathrm{~Hz}$ ) and a $3 \mathrm{H}$ singlet at $\delta_{\mathrm{H}} 3.84$, indicating a 3,4-dihydroxy-5-methoxyphenyl group. The molecular formula of compound 4 was determined to be $\mathrm{C}_{22} \mathrm{H}_{28} \mathrm{O}_{8}$, consisting of a $\mathrm{CH}_{2}$ unit less than 1. Its $1 \mathrm{D} \mathrm{NMR}$ data for the phenyl group at $\mathrm{C}-7$ were similar to those of $\mathbf{1}$ and the resonances for the $\mathrm{C}-1$ phenyl group were almost identical with those of $\mathbf{3}$ (Tables 1 and 2), indicating a 3'-O-demethyl derivative of $\mathbf{1}$. Compound $\mathbf{5}$ had a molecular formula of $\mathrm{C}_{25} \mathrm{H}_{32} \mathrm{O}_{9}$, requiring an additional $\mathrm{C}_{2} \mathrm{H}_{2} \mathrm{O}$ unit compared with that of 1. Its $1 \mathrm{D}$ NMR spectra differed from those of 1 in the presence of additional signals $\left[\delta_{\mathrm{H}} 2.06(3 \mathrm{H}, \mathrm{s}) ; \delta_{\mathrm{C}}\right.$ $21.4,170.8]$ for an acetyl group, which was attached to $\mathrm{C}-3$ via an ester linkage as indicated by the downfield shift of $\mathrm{H}-3\left(\delta_{\mathrm{H}} 5.02\right)$, suggesting a 3-O-acetyl derivative of 1 . The above structures deduced for $\mathbf{2}-\mathbf{5}$ were also supported by COSY, HSQC, and HMBC spectra. Their stereochemistries were all assigned to be the same as that of $\mathbf{1}$ on the basis of ${ }^{1} \mathrm{H}$ NMR coupling constants and NOESY correlations as well as by the similarity of their ECD spectra with that of 1 (Fig. 4). Therefore, the structures of these compound were elucidated as $(1 S, 3 R, 5 S)$-1,5-epoxy-1-(4hydroxy-3,5-dimethoxyphenyl)-7-(4-hydroxy-3-methoxyphenyl)heptan-3-ol (2), (1S,3R,5S)-1,5-epoxy-1-(3,4-dihydroxy-5-methoxyphenyl)-7-(4-hydroxy-3-methoxyphenyl) heptan-3-ol (3), (1S,3R,5S)-1,5-epoxy-1-(3,4-dihydroxy5-methoxyphenyl)-7-(4-hydroxy-3,5-dimethoxyphenyl) heptan-3-ol (4), (1S,3R,5S)-3-O-aceyl-1,5-epoxy-1,7-bis(4hydroxy-3,5-dimethoxyphenyl)heptan-3-ol (5). It is noted that two diarylheptanoids of unknown absolute configurations isolated from ginger [21] had been reported to possess the same planar and relative stereochemical structures as $\mathbf{2}$ and $\mathbf{3}$ and they had optical rotations $\left([\alpha]_{\mathrm{D}}\right)$ with values similar but sign opposite to those of $\mathbf{2}$ and $\mathbf{3}$, indicating the reported compounds are likely the enantiomers of our compounds.

Coriandralpinin $\mathrm{F}$ (6) had a molecular formula of $\mathrm{C}_{23} \mathrm{H}_{28} \mathrm{O}_{9}$ according to HRESIMS data. Its UV spectrum was largely similar to those of $\mathbf{1}-\mathbf{5}$ but differed in that the absorption maximum at the longest wavelength was significantly red-shifted ( $301 \mathrm{~nm}$ vs $271-280 \mathrm{~nm}$ ), suggesting the presence of a chromophore with extended conjugated system. This finding was consistent with the ${ }^{1} \mathrm{H}$ and ${ }^{13} \mathrm{C}$ NMR data (Tables 1 and 2), which were comparable to those of $\mathbf{1}$ except the carbon signal indicating the presence of a conjugated ketone carbonyl $\left(\delta_{\mathrm{C}} 199.5\right)$ and the absence of proton and carbon resonances for C-7 methylene. Detailed analysis

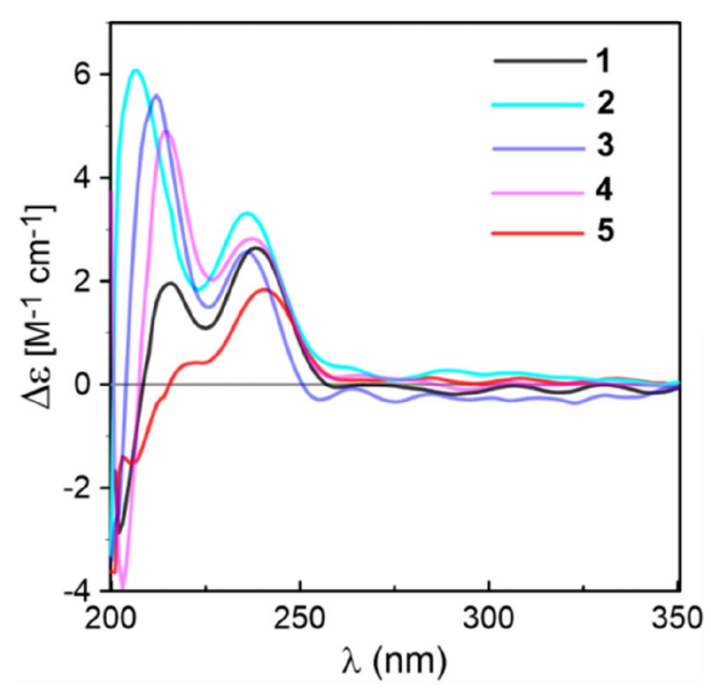

Fig. 4 Comparison of the ECD spectra measured for 1-5 


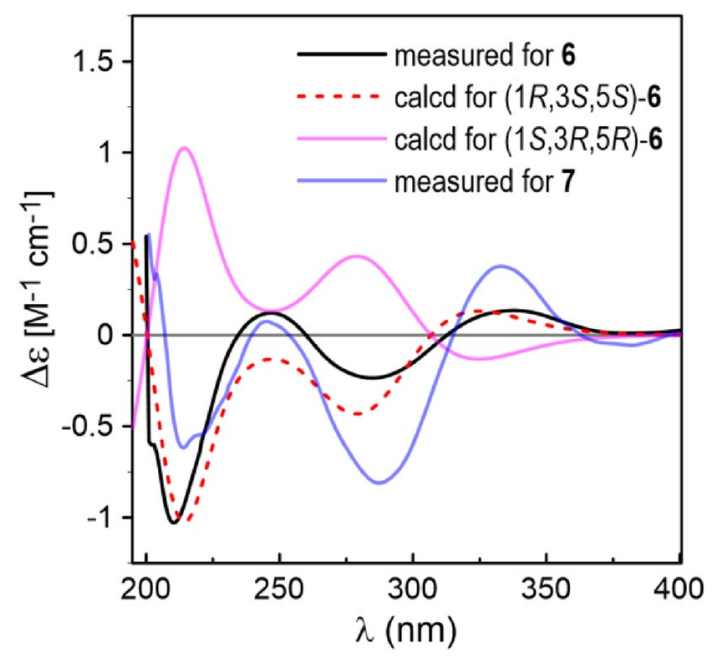

Fig. 5 Comparison of the measured ECD spectra of $\mathbf{6}$ and 7 with $\mathrm{PBE} 0 / \mathrm{TZVP} / \mathrm{PCM}(\mathrm{MeOH})$ calculated ECD spectra of $(1 R, 3 S, 5 S)$ and $(1 S, 3 R, 5 R)-6(\sigma=0.38$, shift $=-11 \mathrm{~nm})$

of the 1D and 2D NMR data readily derived a structure of 7-keto derivative of $\mathbf{1}$, including the relative stereochemistry. As the experimental ECD spectrum of $\mathbf{6}$ was significantly different from the spectrum of $\mathbf{1}$, theoretical computations of ECD spectrum were carried out in order to solve the absolute stereochemistry. As a result (Fig. 5), chiral carbons in $\mathbf{6}$ were shown to be inverted relative to those in $\mathbf{1 - 5}$, designating this compound as $1 R, 3 S, 5 S$. Coriandralpinin $\mathrm{G}$ (7) was a 3"- $O$-demethyl derivative of 6 as elucidated by analysis of the 1D NMR (Tables 1 and 2), 2D NMR, and HRESIMS data. Its absolute stereochemistry was assigned to be the same as that of $\mathbf{6}$ based on the nearly parallel experimental ECD curves of the two compounds (Fig. 5). Thus, the structures of compounds $\mathbf{6}$ and $\mathbf{7}$ were established to be $(1 R, 3 S, 5 S)$-1,5-epoxy-3-hydroxy-1,7-bis(4-hydroxy3,5-dimethoxyphenyl)heptan-7-one and $(1 R, 3 S, 5 S)-1,5$ epoxy-3-hydroxy-1-(4-hydroxy-3,5-dimethoxyphenyl)-7(3,4-dihydroxy-5-methoxyphenyl)heptan-7-one, respectively.

The planar structure of the last diarylheptanoid, coriandralpinin $\mathrm{H}(\mathbf{8})$, was established to be 7-methoxylated $\mathbf{1}$ by analysis of NMR and MS data. Different from the other analogues, compound 8 had one more chiral center C-7, which brought a challenge of solving its stereochemistry. Analysis of proton coupling constants (Table 1) and NOESY data readily assigned the relative configuration of tetrahydropyran ring to be the same as that in $\mathbf{1 - 7}$, but gave no clear information for the configuration at C-7. In order to assign the absolute configuration of $\mathbf{8}, \mathrm{ECD} / \mathrm{TDDFT}$ calculations were carried out for $1 S, 3 R, 5 R, 7 R$ and $1 S, 3 R, 5 R, 7 S$ stereoisomers. Unfortunately, the simulated ECD spectrum of $(1 S, 3 R, 5 R, 7 S)-\mathbf{8}$ and the mirror-image of the calculated spectrum for $(1 S, 3 R, 5 R, 7 R)-\mathbf{8}$ were both in good agreement with the measured spectrum of 8 (Fig. 6). To

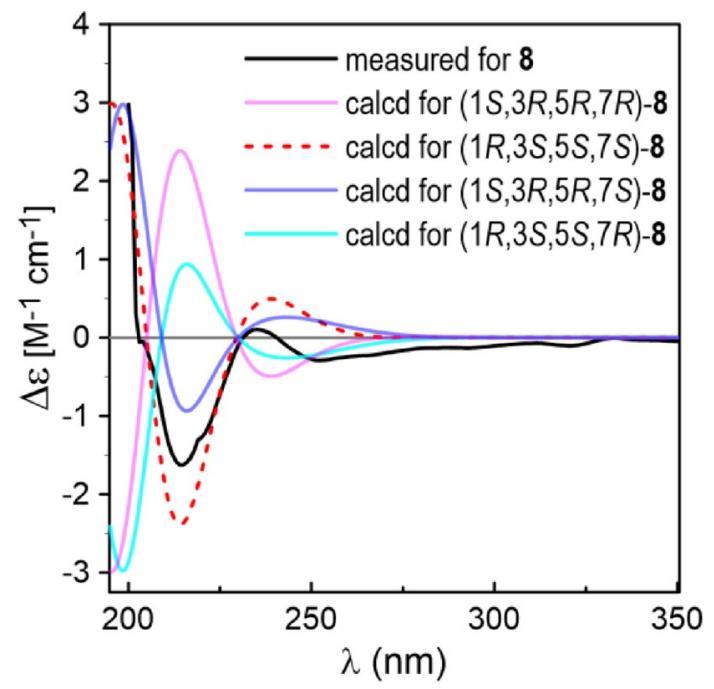

Fig. 6 Comparison between the ECD spectra measured for $\mathbf{8}$ and $\mathrm{PBE} 0 / \mathrm{TZVP} / \mathrm{PCM}$ calculated for four possible stereoisomers of $\mathbf{8}$ $(\sigma=0.38$, shift $=-2 \mathrm{~nm})$

further define the absolute configuration, ${ }^{13} \mathrm{C}$ NMR shifts of $(1 S, 3 R, 5 R, 7 R)-\mathbf{8}$ and $(1 S, 3 R, 5 R, 7 S)-\mathbf{8}$ were calculated using the gauge including atomic orbitals (GIAO) method at the mPW1PW91/6-311+G(d,p)/PCM level of theory. The calculated ${ }^{13} \mathrm{C}$ NMR data of $(1 S, 3 R, 5 R, 7 R)-\mathbf{8}$ showed a better match with the measured data of $\mathbf{8}(\mathrm{DP} 4+$ probability: $98.4 \%)$ than $(1 S, 3 R, 5 R, 7 S)-8$ (DP4 + probability: $1.6 \%)$ (Fig. 7), suggesting a $1 S, 3 R, 5 R, 7 R$ or $1 R, 3 S, 5 S, 7 S$ configuration. This, together with the results of ECD simulations, allowed designation of $\mathbf{8}$ as $1 R, 3 S, 5 S, 7 S$. In consequence, the structure of $\mathbf{8}$ was determined as $(1 R, 3 S, 5 S, 7 S)$-1,5-epoxy7-methoxy-1,7-bis(4-hydroxy-3,5-dimethoxyphenyl) heptan-3-ol.

The isolated known flavonoids were identified to be 7,4'-di- $O$-methylkaempferol (9) [22], 7- $O$-methylquercetin (10) [23], 7,4'-di- $O$-methylquercetin (11) [24], 7,3', $4^{\prime}$-tri$O$-methyl-quercetin (12) [25], kaempferol 3-O- $\beta$-D-(6$O-\alpha$-L-rhamnopyranosyl)glucopyranoside (13) [26], and 3-O- $\beta$-D-glucopyranuronosylquercetin (14) [27] (Fig. S1, Supplementary Material) by interpretation of their spectroscopic data as well as by comparison of the data with reported values in literatures.

Compounds 1-8 were evaluated for antioxidant and anti-inflammatory activities in respect that the two activities are of the most common and interesting biological properties of diarylheptanoids [28-30]. The antioxidant activity evaluation was conducted using a more physiologically relevant method, the cellular antioxidant activity (CAA) assay [29, 30], with RAW 264.7 macrophages as the test cells. The concentrations of compounds used in the assay were $50 \mu \mathrm{M}$ and lowers according to cell viability assay by MTT method, which showed that 1-8 had no 
$(1 S, 3 R, 5 R, 7 R)-8$

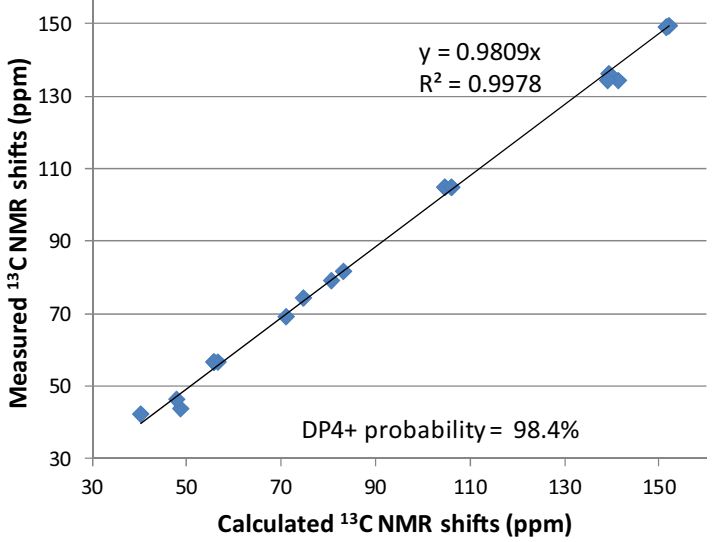

$(1 S, 3 R, 5 R, 7 S)-8$

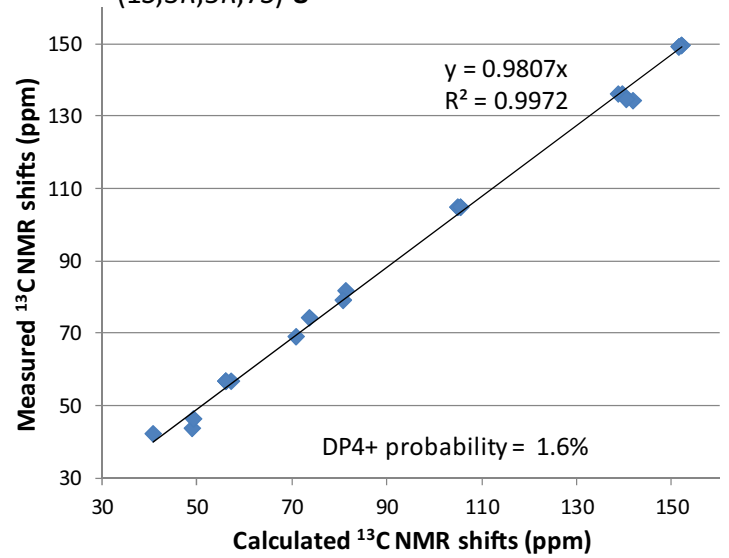

Fig. 7 Linear regression analysis of the calculated ${ }^{13} \mathrm{C}$ NMR shifts of two possible stereoisomers against the measured shifts of 8 and the DP4 + probability for 8 to be the stereoisomers

observable toxicity to RAW 264.7 cells at the concentration up to $100 \mu \mathrm{M}$. As indicated in Fig. 8 and Table 3, all these compounds were capable of significantly decreasing $t$-BHP-induced ROS production in RAW 264.7 cells in a concentration-dependent manner (Fig. 8), although none of them was more potent than the positive control curcumin. Among them, 3'- or 3"'-OH bearing 3, 4, and 7 exhibited better activity $\left(\mathrm{IC}_{50}: 12.0-18.0 \mu \mathrm{M}\right)$ than their corresponding 3'- or 3"- $O$-methyl derivatives $\mathbf{2 ,} 5$, and $\mathbf{6}$ (Table 3). Besides, the change of 7-keto carbonyl to the methoxylated methine was shown to increase the activity (6 vs 8).
The potential anti-inflammatory activity of compounds 1-8 was evaluated by measuring their inhibitory effects on nitric oxide (NO) production in lipopolysaccharide (LPS)-induced RAW 264.7 cells (Table 3). Among these diarylheptanoids, compounds $\mathbf{3}$ and $\mathbf{5}$ exhibited inhibitory activity against $\mathrm{NO}$ release with $\mathrm{IC}_{50}$ values of 36.9 and $34.1 \mu \mathrm{M}$, respectively, which were comparable to that of the positive drug control dexamethasone $\left(\mathrm{IC}_{50}: 33.6 \mu \mathrm{M}\right)$. However, other isolated analogues were inactive in the assay $\left(\mathrm{IC}_{50}>50 \mu \mathrm{M}\right)$.

In summary, phytochemical analysis of $A$. Coriandriodora rhizomes led to the characterization of a group of

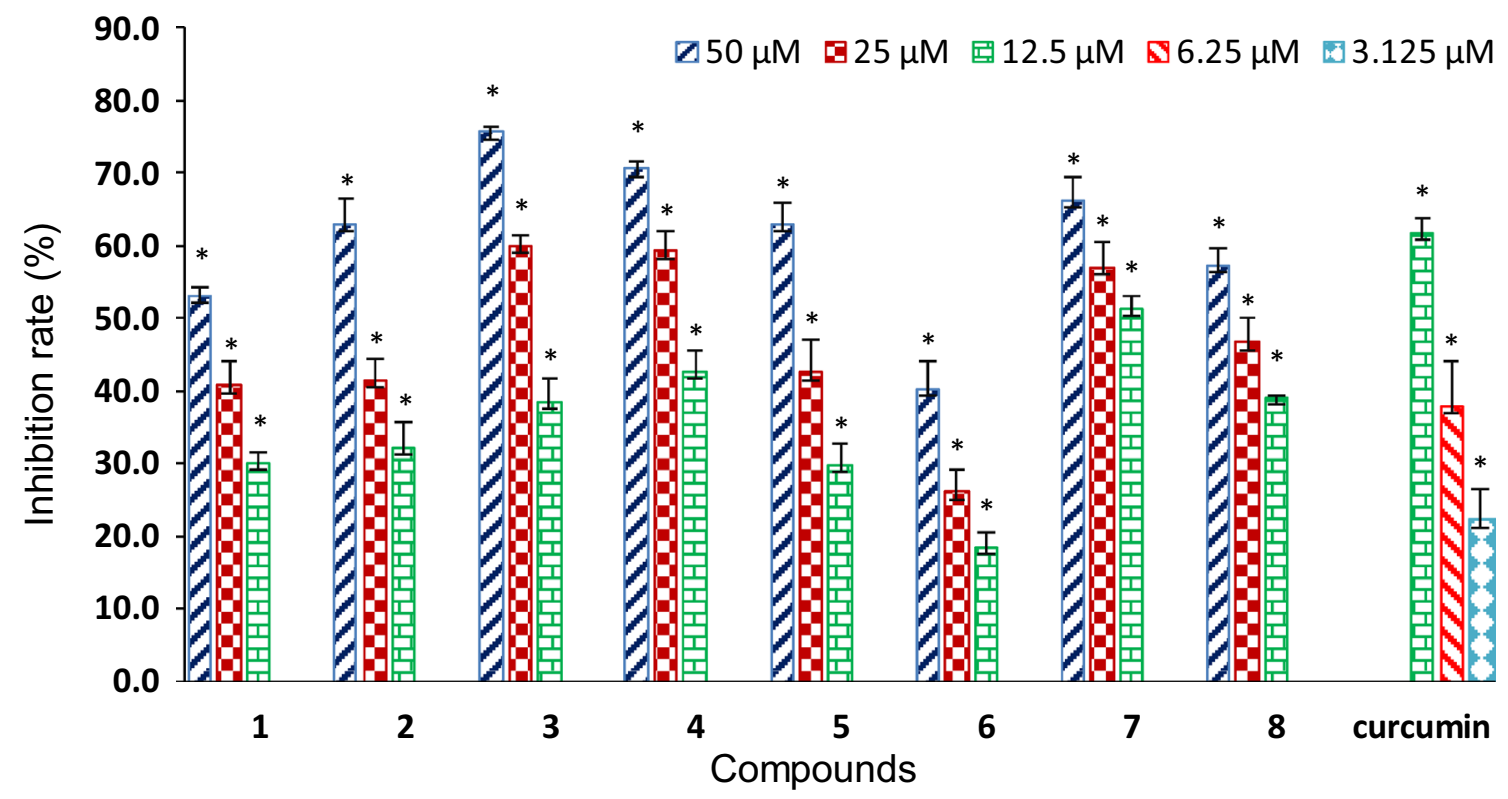

Fig. 8 Concentration-dependent inhibition of $t$-BHP-induced ROS production in RAW264.7 cells by compounds 1-8 and the positive control curcumin $\left({ }^{*} P<0.05\right.$ vs $t$-BHP alone) 
Table $1{ }^{1} \mathrm{H}$ NMR (500 MHz) data for compounds 1-8

\begin{tabular}{|c|c|c|c|c|c|c|c|c|}
\hline position & $\mathbf{1}^{a}$ & $2^{a}$ & $\mathbf{3}^{b}$ & $4^{b}$ & $\mathbf{5}^{a}$ & $6^{b}$ & $7^{b}$ & $\mathbf{8}^{b}$ \\
\hline 1 & $\begin{array}{l}4.26 \mathrm{dd}(11.4, \\
2.0)\end{array}$ & $\begin{array}{l}4.26 \mathrm{dd}(11.4, \\
2.0)\end{array}$ & $\begin{array}{l}4.19 \mathrm{dd}(11.4, \\
1.9)\end{array}$ & $\begin{array}{l}4.18 \mathrm{dd}(11.4, \\
1.9)\end{array}$ & $\begin{array}{l}4.33 \mathrm{dd}(11.5 \\
2.0)\end{array}$ & $\begin{array}{l}4.34 \mathrm{dd}(11.4, \\
1.9)\end{array}$ & $4.32 \mathrm{~d}(10.1)$ & $4.30-4.36 \mathrm{~m}$ \\
\hline 2 & $\begin{array}{l}\text { ax } 1.50 \mathrm{q} \\
(11.4) \\
\text { eq } 2.20 \mathrm{ddt} \\
(12.5,4.3 \text {, } \\
2.0)\end{array}$ & $\begin{array}{l}\text { ax } 1.51 \mathrm{q} \\
(11.4) \\
\text { eq } 2.20 \mathrm{ddt} \\
(12.5,4.3 \text {, } \\
2.0)\end{array}$ & $\begin{array}{l}\text { ax } 1.41 \mathrm{q} \\
(11.4) \\
\text { eq } 2.08 \mathrm{ddt} \\
(12.5,4.3 \text {, } \\
2.0)\end{array}$ & $\begin{array}{l}\text { ax } 1.41 \mathrm{q} \\
(11.4) \\
\text { eq } 2.08 \mathrm{ddt} \\
(12.4,4.2, \\
1.9)\end{array}$ & $\begin{array}{l}\text { ax } 1.59 \mathrm{q} \\
(11.7) \\
\text { eq } 2.23 \text { br d } \\
(12.7,4.1 \text {, } \\
1.8)\end{array}$ & $\begin{array}{r}\text { ax } 1.36- \\
1.46 \mathrm{~m} \\
\text { eq } 2.11- \\
2.17 \mathrm{~m}\end{array}$ & $\begin{array}{c}\text { ax } 1.34- \\
1.44 \mathrm{~m} \\
\text { eq } 2.10- \\
2.18 \mathrm{~m}\end{array}$ & $\begin{array}{l}\text { ax } 1.46 \mathrm{q}(11.6) \\
\text { eq } 2.13 \mathrm{ddt} \\
(12.4,4.0,1.6)\end{array}$ \\
\hline 3 & $3.94 \mathrm{~m}$ & $3.95 \mathrm{~m}$ & $3.81 \mathrm{~m}$ & $3.82 \mathrm{~m}$ & $5.02 \mathrm{~m}$ & $3.93 \mathrm{~m}$ & $3.95 \mathrm{~m}$ & $3.90 \mathrm{~m}$ \\
\hline 4 & $\begin{array}{l}\text { ax } 1.33 \mathrm{q} \\
(11.4) \\
\text { eq } 2.03 \mathrm{ddt} \\
(12.2,4.1 \text {, } \\
1.8)\end{array}$ & $\begin{array}{l}\text { ax } 1.33 \mathrm{q} \\
(11.4) \\
\text { eq } 2.03 \mathrm{ddt} \\
(12.3,4.1 \text {, } \\
1.9)\end{array}$ & $\begin{array}{l}\text { ax } 1.23 \mathrm{q} \\
(11.5) \\
\text { eq } 1.95 \mathrm{ddt} \\
(12.4,4.4, \\
1.9)\end{array}$ & $\begin{array}{l}\text { ax } 1.23 \mathrm{q} \\
(11.3) \\
\text { eq } 1.94 \mathrm{ddt} \\
(12.3,4.3 \text {, } \\
1.9)\end{array}$ & $\begin{array}{c}\text { ax } 1.44 \mathrm{q} \\
(11.6) \\
\text { eq } 2.09 \mathrm{~m}\end{array}$ & $\begin{array}{r}\text { ax } 1.36- \\
1.46 \mathrm{~m} \\
\text { eq } 2.11- \\
2.17 \mathrm{~m}\end{array}$ & $\begin{array}{r}\text { ax } 1.34- \\
1.44 \mathrm{~m} \\
\text { eq } 2.10- \\
2.18 \mathrm{~m}\end{array}$ & $\begin{array}{l}\text { ax } 1.24 \mathrm{q}(11.6) \\
\text { eq } 2.01 \mathrm{ddt} \\
\quad(12.4,4.0,1.7)\end{array}$ \\
\hline 5 & $3.45 \mathrm{~m}$ & $3.45 \mathrm{~m}$ & $3.42 \mathrm{~m}$ & $3.40 \mathrm{~m}$ & $3.51 \mathrm{~m}$ & $4.10 \mathrm{~m}$ & $4.10 \mathrm{~m}$ & $3.76 \mathrm{~m}$ \\
\hline 6 & $\begin{array}{l}1.98 \mathrm{~m} \\
1.81 \mathrm{~m}\end{array}$ & $\begin{array}{l}1.98 \mathrm{~m} \\
1.80 \mathrm{~m}\end{array}$ & $\begin{array}{l}1.87 \mathrm{~m} \\
1.75 \mathrm{~m}\end{array}$ & $\begin{array}{l}1.75 \mathrm{~m} \\
1.87 \mathrm{~m}\end{array}$ & $\begin{array}{l}1.99 \mathrm{~m} \\
1.81 \mathrm{~m}\end{array}$ & $\begin{array}{l}3.36 \mathrm{dd}(15.2, \\
7.1) \\
3.08 \mathrm{dd}(15.2, \\
5.0)\end{array}$ & $\begin{array}{l}3.35 \text { dd }(15.1, \\
7.1) \\
2.98 \text { dd }(15.1, \\
5.2)\end{array}$ & $\begin{array}{l}1.93 \mathrm{~m} \\
1.83 \mathrm{~m}\end{array}$ \\
\hline 7 & $2.67-2.75 \mathrm{~m}$ & $2.64-2.77 \mathrm{~m}$ & $2.61-2.72 \mathrm{~m}$ & $2.61-2.71 \mathrm{~m}$ & $2.61-2.73 \mathrm{~m}$ & & & $4.30-4.36 \mathrm{~m}$ \\
\hline $2^{\prime}$ & $6.63 \mathrm{~s}$ & $6.62 \mathrm{~s}$ & $6.54 \mathrm{~d}(2.0)$ & $6.55 \mathrm{~d}(1.9)$ & $6.61 \mathrm{~s}$ & $6.54 \mathrm{~s}$ & $6.54 \mathrm{~s}$ & $6.67 \mathrm{~s}$ \\
\hline $6^{\prime}$ & $6.63 \mathrm{~s}$ & $6.62 \mathrm{~s}$ & $6.53 \mathrm{~d}(2.0)$ & $6.53 \mathrm{~d}(1.9)$ & $6.61 \mathrm{~s}$ & $6.54 \mathrm{~s}$ & $6.54 \mathrm{~s}$ & $6.67 \mathrm{~s}$ \\
\hline $2^{\prime \prime}$ & $6.41 \mathrm{~s}$ & $6.69 \mathrm{~d}(1.9)$ & $6.76 \mathrm{~d}(2.0)$ & $6.45 \mathrm{~s}$ & $6.40 \mathrm{~s}$ & $7.36 \mathrm{~s}$ & $7.23 \mathrm{~d}(2.0)$ & $6.58 \mathrm{~s}$ \\
\hline $3^{\prime \prime}$ & & $6.82 \mathrm{~d}(8.0)$ & $6.69 \mathrm{~d}(8.0)$ & & & & & \\
\hline $6^{\prime \prime}$ & $6.41 \mathrm{~s}$ & $\begin{array}{l}6.68 \mathrm{dd} \\
\quad(8.0,1.9)\end{array}$ & $\begin{array}{l}6.62 \mathrm{dd}(8.0, \\
2.0)\end{array}$ & $6.45 \mathrm{~s}$ & $6.40 \mathrm{~s}$ & $7.36 \mathrm{~s}$ & $7.20 \mathrm{~d}(2.0)$ & $6.58 \mathrm{~s}$ \\
\hline $7-\mathrm{OCH}_{3}$ & & & & & & & & $3.19 \mathrm{~s}$ \\
\hline $3^{\prime}-\mathrm{OCH}_{3}$ & $3.90 \mathrm{~s}$ & $3.90 \mathrm{~s}$ & & & $3.90 \mathrm{~s}$ & $3.85 \mathrm{~s}$ & $3.75 \mathrm{~s}$ & $3.85 \mathrm{~s}$ \\
\hline $5^{\prime}-\mathrm{OCH}_{3}$ & $3.90 \mathrm{~s}$ & $3.90 \mathrm{~s}$ & $3.84 \mathrm{~s}$ & $3.83 \mathrm{~s}$ & $3.90 \mathrm{~s}$ & $3.85 \mathrm{~s}$ & $3.75 \mathrm{~s}$ & $3.85 \mathrm{~s}$ \\
\hline $3^{\prime \prime}-\mathrm{OCH}_{3}$ & $3.84 \mathrm{~s}$ & & & $3.77 \mathrm{~s}$ & $3.84 \mathrm{~s}$ & $3.74 \mathrm{~s}$ & & $3.81 \mathrm{~s}$ \\
\hline $5^{\prime \prime}-\mathrm{OCH}_{3}$ & $3.84 \mathrm{~s}$ & $3.83 \mathrm{~s}$ & $3.78 \mathrm{~s}$ & $3.77 \mathrm{~s}$ & $3.84 \mathrm{~s}$ & $3.74 \mathrm{~s}$ & $3.84 \mathrm{~s}$ & $3.81 \mathrm{~s}$ \\
\hline $\mathrm{CH}_{3} \mathrm{CO}$ & & & & & $2.06 \mathrm{~s}$ & & & \\
\hline
\end{tabular}

${ }^{\mathrm{a}} \mathrm{CDCl}_{3}$ used as solvent

${ }^{\mathrm{b}} \mathrm{CD}_{3} \mathrm{OD}$ used as solvent

unique 1,5-O-bridged diarylheptanoids, coriandralpinins A-H (1-8). These compounds exhibited remarkable intracellular antioxidant activity in concentration-dependent manner. Compounds $\mathbf{3}$ and $\mathbf{5}$ also inhibited NO release in LPS-induced RAW 264.7 cells. The results suggested that the edible plant $A$. coriandriodora is a potential source for dietary supplements.

\section{Experimental Section}

\subsection{General Experimental Procedures}

Optical rotations were obtained on a Perkin-Elmer 341 polarimeter with $\mathrm{MeOH}$ as solvent. UV and ECD spectra were recorded in $\mathrm{MeOH}$ with a Chirascan $\mathrm{CD}$ spectrometer (Applied Photophysics LTD., England). ${ }^{1} \mathrm{H}$ NMR, ${ }^{13} \mathrm{C}$ NMR, and 2D NMR spectra were recorded in chloroform- $d$ or methanol- $d_{4}$ on a Brucker AVIII $500 \mathrm{M}$ instrument for ${ }^{1} \mathrm{H}$ at 500 and for ${ }^{13} \mathrm{C}$ at $125 \mathrm{MHz}$ using the residual solvent peak as reference. High-resolution electrospray ionization mass spectrometry (HRESIMS) was obtained on Bruker maXis Q-TOF mass spectrometer. ESIMS data were obtained on an MDS SCIEX API 2000 LC/MS instrument (SCIEX, Toronto, Canada). HRESIMS data were obtained on a Bruker Bio TOF IIIQ mass spectrometer (Bruker Daltonics, Billerica, MA, U.S.A.). Preparative HPLC was performed with an HPLC system equipped with a Shimadzu LC-6AD pump (Shimadzu, Kyoto, Japan) using a YMC-pack ODS-A column $(5 \mu \mathrm{m}, 10 \times 250 \mathrm{~mm}$, YMC, Kyoto, Japan). For column chromatography, silica gel 60 (100-200 mesh, Qingdao Marine Chemical Ltd., Qingdao, China) and YMC ODS (75 $\mu \mathrm{m}$, YMC, Kyoto, Japan) were used. TLC was performed using HSGF254 silica gel plates (Yantai Jiangyou Silica Gel Development Co. Ltd., Yantai, China). 
Table $2{ }^{13} \mathrm{C}$ NMR $(125 \mathrm{MHz})$ data for compounds 1-8

\begin{tabular}{|c|c|c|c|c|c|c|c|c|}
\hline Position & $\mathbf{1}^{a}$ & $2^{a}$ & $3^{b}$ & $4^{b}$ & $5^{a}$ & $6^{b}$ & $7^{b}$ & $\mathbf{8}^{b}$ \\
\hline 1 & 77.7 & 77.6 & 79.0 & 79.0 & 77.6 & 79.1 & 78.9 & 79.2 \\
\hline 2 & 43.1 & 42.9 & 43.7 & 43.8 & 39.3 & 43.6 & 43.7 & 43.7 \\
\hline 3 & 68.6 & 68.7 & 69.0 & 69.0 & 70.9 & 68.7 & 68.7 & 69.0 \\
\hline 4 & 41.0 & 40.9 & 41.9 & 41.8 & 37.1 & 41.7 & 41.8 & 42.3 \\
\hline 5 & 75.0 & 75.0 & 76.2 & 76.2 & 75.0 & 74.7 & 74.7 & 74.3 \\
\hline 6 & 37.9 & 37.9 & 39.1 & 39.0 & 37.9 & 45.3 & 45.2 & 46.2 \\
\hline 7 & 32.0 & 31.5 & 32.3 & 32.8 & 32.0 & 199.5 & 199.6 & 81.8 \\
\hline 1 ' & 133.4 & 133.4 & 134.6 & 134.5 & 133.0 & 134.4 & 134.4 & 134.5 \\
\hline $2^{\prime}$ & 103.0 & 103.1 & 108.0 & 108.0 & 103.0 & 104.5 & 104.3 & 104.8 \\
\hline $3^{\prime}$ & 147.1 & 147.1 & 146.4 & 146.4 & 147.1 & 148.9 & 149.0 & 149.1 \\
\hline 4 & 134.3 & 134.0 & 134.5 & 134.2 & 134.3 & 136.5 & 135.8 & 136.0 \\
\hline 5 & 147.1 & 147.1 & 149.5 & 149.4 & 147.1 & 148.9 & 149.0 & 149.1 \\
\hline $6{ }^{\prime}$ & 103.0 & 103.1 & 102.8 & 102.7 & 103.0 & 104.5 & 104.3 & 104.8 \\
\hline $1^{\prime \prime}$ & 133.2 & 134.3 & 135.0 & 134.5 & 133.1 & 129.7 & 129.8 & 134.3 \\
\hline $2^{\prime \prime}$ & 105.2 & 111.2 & 113.3 & 106.7 & 105.2 & 107.8 & 111.6 & 104.8 \\
\hline $3^{\prime \prime}$ & 147.1 & 114.3 & 116.1 & 149.1 & 147.1 & 149.0 & 146.3 & 149.4 \\
\hline $4^{\prime \prime}$ & 132.9 & 143.8 & 145.5 & 134.6 & 133.0 & 142.6 & 141.2 & 135.9 \\
\hline $5^{\prime \prime}$ & 147.1 & 146.5 & 148.8 & 149.1 & 147.1 & 149.0 & 149.2 & 149.4 \\
\hline $6^{\prime \prime}$ & 105.2 & 121.1 & 121.8 & 106.7 & 105.2 & 107.8 & 105.3 & 104.8 \\
\hline 7- $\mathrm{OCH}_{3}$ & & & & & & & & 56.7 \\
\hline $3^{\prime}-\mathrm{OCH}_{3}$ & 56.5 & 56.5 & & & 56.5 & 56.8 & 56.7 & 56.8 \\
\hline $5^{\prime}-\mathrm{OCH}_{3}$ & 56.5 & 56.5 & 56.6 & 56.6 & 56.5 & 56.8 & 56.7 & 56.8 \\
\hline $3^{\prime \prime}-\mathrm{OCH}_{3}$ & 56.4 & & & 56.7 & 56.4 & 56.7 & & 56.7 \\
\hline $5^{\prime \prime}-\mathrm{OCH}_{3}$ & 56.4 & 56.0 & 56.3 & 56.7 & 56.4 & 56.7 & 56.7 & 56.7 \\
\hline $\mathrm{CH}_{3} \mathrm{CO}$ & & & & & 170.8 & & & \\
\hline $\mathrm{CH}_{3} \mathrm{CO}$ & & & & & 21.4 & & & \\
\hline
\end{tabular}

${ }^{\mathrm{a}} \mathrm{CDCl}_{3}$ used as solvent

${ }^{\mathrm{b}} \mathrm{CD}_{3} \mathrm{OD}$ used as solvent
Table 3 Inhibitory activity of compounds $\mathbf{1 - 8}$ against $t$-BHP-induced ROS and LPS-induced NO production in RAW264.7 cells

\begin{tabular}{lll}
\hline compound & $\begin{array}{l}\text { Inhibition of ROS }\left(\mathrm{IC}_{50},\right. \\
\mu \mathrm{M})^{\mathrm{a}}\end{array}$ & $\begin{array}{l}\text { Inhibition of } \\
\mathrm{NO}\left(\mathrm{IC}_{50},\right. \\
\mu \mathrm{M})^{\mathrm{a}}\end{array}$ \\
\hline $\mathbf{1}$ & $43.0 \pm 1.5$ & $>50$ \\
$\mathbf{2}$ & $31.1 \pm 2.6$ & $>50$ \\
$\mathbf{3}$ & $18.0 \pm 0.7$ & $36.9 \pm 1.1$ \\
$\mathbf{4}$ & $17.6 \pm 1.0$ & $>50$ \\
$\mathbf{5}$ & $31.0 \pm 3.3$ & $34.1 \pm 0.6$ \\
$\mathbf{6}$ & $>50$ & $>50$ \\
$\mathbf{7}$ & $12.0 \pm 2.1$ & $>50$ \\
$\mathbf{8}$ & $29.9 \pm 1.8$ & $>50$ \\
Curcumin & $8.6 \pm 0.4$ & $33.6 \pm 1.5$ \\
Dexamethasone & &
\end{tabular}

${ }^{\mathrm{a}}$ Data are presented as mean $\pm \mathrm{SD}(n=3)$

\subsection{Plant Material}

The rhizomes of $A$. Coriandriodora were purchased from Nanning, Guangxi, China, in January 2018. A voucher specimen (specimen number SC-42-3-7) was deposited at the Herbarium of South China Botanical Garden, Chinese Academy of Sciences.

\subsection{Extraction and Isolation}

The fresh rhisomes of $A$. Coriandriodora $(1.55 \mathrm{~kg})$, after being dried at $50{ }^{\circ} \mathrm{C}$ in an oven, were crushed into powder $(260 \mathrm{~g})$ and then extracted with $95 \% \mathrm{EtOH}$ for $48 \mathrm{~h}$ $(\times 3)$. The crude extract (58 g) was suspended in water and extracted successively with petroleum ether (PE), EtOAc, and $n$-BuOH for three times each. The PE-soluble fraction (13 g) was subjected to silica gel column chromatography (CC) using gradient PE-acetone mixtures (v/v, 100:0-60:40) to obtain ten fractions (Fr. A1 to Fr. A10). Fr. A5 (470 mg) was separated by Sephadex LH-20 CC using PE- $\mathrm{CH}_{2} \mathrm{Cl}_{2}-\mathrm{MeOH}(1: 1: 1)$ to afford 
compound 9 (150 mg). Fr. A10 was applied to ODS CC using $\mathrm{MeOH}-\mathrm{H}_{2} \mathrm{O}(\mathrm{v} / \mathrm{v}, 30: 70-100: 0)$ to give ten subfractions (Fr. A10-1 to Fr. A10-10). Fr. A10-9 (12 mg) and Fr. A10-10 (30 mg) were further separated by Sephadex LH-20 CC using PE- $\mathrm{CH}_{2} \mathrm{Cl}_{2}-\mathrm{MeOH}$ (1:1:1) to obtain 11 $(3 \mathrm{mg})$ and $12(25 \mathrm{mg})$, respectively. Fr. A10-5 (6 mg) was purified by preparative HPLC using $30 \% \mathrm{MeCN}$ to afford $10\left(1 \mathrm{mg}, t_{\mathrm{R}}=25.6 \mathrm{~min}\right)$. The EtOAc-soluble fraction $(11.42 \mathrm{~g})$ was subjected to silica gel CC, eluted with gradient $\mathrm{CH}_{2} \mathrm{Cl}_{2}-\mathrm{MeOH}$ mixtures (v/v, 100:0 to 50:50), to afford eleven fractions (Fr. B1 to Fr. B11). Fr. B5 (271 mg) was chromatographed on a Sephadex LH-20 column using PE- $\mathrm{CH}_{2} \mathrm{Cl}_{2}-\mathrm{MeOH}(1: 1: 1)$ to yield 1 (244 mg). Fr. B6 $(1.17 \mathrm{~g})$ was further applied to ODS $\mathrm{CC}$ using $\mathrm{MeOH}-$ $\mathrm{H}_{2} \mathrm{O}$ (v/v, 1:9 to 10:0) to yield eleven subfractions ( $\mathrm{Fr}$. B6-1 to Fr. B6-11). Fr. B6-4 was subjected to Sephadex LH-20 CC using PE- $\mathrm{CH}_{2} \mathrm{Cl}_{2}-\mathrm{MeOH}(1: 1: 1)$ followed by preparative HPLC to yield $6\left(2 \mathrm{mg}, t_{\mathrm{R}}=36.6 \mathrm{~min}\right)$ and $2\left(9 \mathrm{mg}, t_{\mathrm{R}}=95.0 \mathrm{~min}\right)$ using $20 \% \mathrm{CH}_{3} \mathrm{CN}$ and $\mathbf{5}(5 \mathrm{mg}$, $\left.t_{\mathrm{R}}=79.6 \mathrm{~min}\right)$ using $34 \% \mathrm{CH}_{3} \mathrm{CN}$. Fr. B8 (3.42 g) was subjected to ODS CC using $\mathrm{MeOH}-\mathrm{H}_{2} \mathrm{O}$ (v/v, 1:9 to 10:0) to give twelve subfractions (Fr. B8-1 to Fr. B8-12). Fr. B8-4 was further separated by HPLC using $17 \% \mathrm{CH}_{3} \mathrm{CN}$ to afford $7\left(10 \mathrm{mg}, t_{\mathrm{R}}=27.1 \mathrm{~min}\right)$. Fr. B8-5 was subjected to Sephadex LH-20 CC using PE- $\mathrm{CH}_{2} \mathrm{Cl}_{2}-\mathrm{MeOH}(1: 1: 1)$ followed by preparative HPLC using $20 \% \mathrm{CH}_{3} \mathrm{CN}$ to yield $8\left(3 \mathrm{mg}, t_{\mathrm{R}}=51.1 \mathrm{~min}\right), 4\left(76 \mathrm{mg}, t_{\mathrm{R}}=45.3 \mathrm{~min}\right)$, and $\mathbf{3}$ $\left(11 \mathrm{mg}, t_{\mathrm{R}}=54.1 \mathrm{~min}\right)$. The $n$-BuOH-soluble fraction $(1 \mathrm{~g})$ was subjected ODS CC using $\mathrm{MeOH}-\mathrm{H}_{2} \mathrm{O}$ (v/v, 1:9-3:7) to give three fractions (Fr. C1 to Fr. C3). Fr. C1 (141 mg) was separated by preparative HPLC using $22 \% \mathrm{MeCN}$ to afford $13\left(22 \mathrm{mg}, t_{\mathrm{R}}=11.2 \mathrm{~min}\right)$ and $\mathbf{1 4}\left(8 \mathrm{mg}, t_{\mathrm{R}}=13.0 \mathrm{~min}\right)$.

Coriandralpinin A (1): light brown oil; $[\alpha]_{\mathrm{D}}^{20}+51.1(c$ $0.33, \mathrm{MeOH}) ; \mathrm{UV}(\mathrm{MeOH}) \lambda_{\max } \mathrm{nm}(\log \varepsilon): 206$ (3.93), 230 (3.12), 272 (2.30); CD (MeOH) $\Delta \varepsilon 219$ (+1.97), 239 $(+2.63) ;{ }^{1} \mathrm{H}$ and ${ }^{13} \mathrm{C}$ NMR data were depicted Tables 1 and 2. HRESIMS $m / z 435.2009[\mathrm{M}+\mathrm{H}]^{+}$(calcd for $\mathrm{C}_{23} \mathrm{H}_{31} \mathrm{O}_{8}$, 435.2014), $\mathrm{m} / z 457.1836[\mathrm{M}+\mathrm{Na}]^{+}\left(\right.$calcd for $\mathrm{C}_{23} \mathrm{H}_{30} \mathrm{NaO}_{8}$, 457.1833).

Coriandralpinin B (2): light brown oil, $[\alpha]_{\mathrm{D}}^{20}+54.5(c$ $0.70, \mathrm{MeOH}) . \mathrm{UV}(\mathrm{MeOH}) \lambda_{\max } \mathrm{nm}(\log \varepsilon): 202$ (3.96), 230 (3.20), 280 (2.72); $\mathrm{CD}(\mathrm{MeOH}) \Delta \varepsilon 207$ (+6.07), 236 $(+3.31) ;{ }^{1} \mathrm{H}$ and ${ }^{13} \mathrm{C}$ NMR data were depicted Tables 1 and 2. (+)-HRESIMS: $\mathrm{m} / z 405.1914[\mathrm{M}+\mathrm{H}]^{+}$(calcd for $\mathrm{C}_{22} \mathrm{H}_{29} \mathrm{O}_{7}, 405.1908$ ), $\mathrm{m} / z 427.1736[\mathrm{M}+\mathrm{Na}]^{+}$(calcd for $\mathrm{C}_{22} \mathrm{H}_{28} \mathrm{NaO}_{7}, 427.1728$ ).

Coriandralpinin C (3): light yellow oil, $[\alpha]_{\mathrm{D}}^{20}+54.9(c$ 0.99, MeOH). UV (MeOH) $\lambda_{\max } \mathrm{nm}(\log \varepsilon): 201$ (4.00), 230 (3.24), 279 (2.71); $\mathrm{CD}(\mathrm{MeOH}) \Delta \varepsilon 212$ (+5.59), 236 $(+2.57) ;{ }^{1} \mathrm{H}$ and ${ }^{13} \mathrm{C}$ NMR data were depicted Tables 1 and 2. (+)-HRESIMS: $m / z 391.1748[\mathrm{M}+\mathrm{H}]^{+}$(calcd for $\mathrm{C}_{21} \mathrm{H}_{27} \mathrm{O}_{7}, 391.1752$ ), $\mathrm{m} / \mathrm{z} 413.1571[\mathrm{M}+\mathrm{Na}]^{+}$(calcd for $\left.\mathrm{C}_{21} \mathrm{H}_{26} \mathrm{NaO}_{7}, 413.1571\right)$.
Coriandralpinin D (4): orange oil, $[\alpha]_{\mathrm{D}}^{20}+56.4(c$ $0.25, \mathrm{MeOH})$. UV (MeOH) $\lambda_{\max } \mathrm{nm}(\log \varepsilon): 205$ (3.97), 229 (3.18), 271 (2.31); CD (MeOH) $\Delta \varepsilon 214$ (+4.89), 237 $(+2.82) ;{ }^{1} \mathrm{H}$ and ${ }^{13} \mathrm{C}$ NMR data were depicted Tables 1 and 2. (+)-HRESIMS: $m / z 421.1851[\mathrm{M}+\mathrm{H}]^{+}$(calcd for $\mathrm{C}_{22} \mathrm{H}_{29} \mathrm{O}_{8}, 421.1857$ ), $\mathrm{m} / \mathrm{z} 443.1674[\mathrm{M}+\mathrm{Na}]^{+}$(calcd for $\left.\mathrm{C}_{22} \mathrm{H}_{28} \mathrm{NaO}_{8}, 443.1677\right)$.

Coriandralpinin E (5): light yellow oil, $[\alpha]_{\mathrm{D}}^{20}+34.8(c$ $0.56, \mathrm{MeOH}) . \mathrm{UV}(\mathrm{MeOH}) \lambda_{\max } \mathrm{nm}(\log \varepsilon): 206$ (3.90), 230 (3.10), 271 (2.30); $\mathrm{CD}(\mathrm{MeOH}) \Delta \varepsilon 223$ (+0.42), 241 $(+1.83) ;{ }^{1} \mathrm{H}$ and ${ }^{13} \mathrm{C}$ NMR data were depicted Tables 1 and 2. (+)-HRESIMS: $m / z 477.2114[\mathrm{M}+\mathrm{H}]^{+}$(calcd for $\mathrm{C}_{25} \mathrm{H}_{33} \mathrm{O}_{9}, 477.2120$ ), $\mathrm{m} / z$ 499.1934 [M+Na] ${ }^{+}$(calcd for $\mathrm{C}_{25} \mathrm{H}_{32} \mathrm{NaO}_{9}, 499.1939$ ).

Coriandralpinin $\mathrm{F}(6)$ : light brown oil, $[\alpha]_{\mathrm{D}}^{20}+10.3(c$ $0.18, \mathrm{MeOH})$. UV (MeOH) $\lambda_{\max } \mathrm{nm}(\log \varepsilon): 206$ (3.47), 225 (3.06), 301 (2.72); $\mathrm{CD}(\mathrm{MeOH}) \Delta \varepsilon 210$ (-1.03), 285 $(-0.24), 338(+0.14) ;{ }^{1} \mathrm{H}$ and ${ }^{13} \mathrm{C}$ NMR data were depicted Tables 1 and 2. $(+)$-HRESIMS: $m / z 449.1804[\mathrm{M}+\mathrm{H}]^{+}$ (calcd for $\mathrm{C}_{23} \mathrm{H}_{29} \mathrm{O}_{9}, 449.1807$ ), $\mathrm{m} / z$ 471.1623 [M+Na] ${ }^{+}$ (calcd for $\mathrm{C}_{23} \mathrm{H}_{28} \mathrm{NaO}_{9}, 471.1626$ ).

Coriandralpinin G (7): yellow oil, $[\alpha]_{\mathrm{D}}^{20}+19.8(c$ $0.81, \mathrm{MeOH})$. UV (MeOH) $\lambda_{\max } \mathrm{nm}(\log \varepsilon): 206$ (3.77), 225 (3.33), 301 (2.72); $\mathrm{CD}(\mathrm{MeOH}) \Delta \varepsilon 214$ (-0.62), 287 $(-0.81), 333(+0.38) ;{ }^{1} \mathrm{H}$ and ${ }^{13} \mathrm{C}$ NMR data were depicted Tables 1 and 2. $(+)$-HRESIMS: $m / z 435.1658[\mathrm{M}+\mathrm{H}]^{+}$ (calcd for $\mathrm{C}_{22} \mathrm{H}_{27} \mathrm{O}_{9}, 435.1650$ ), $\mathrm{m} / \mathrm{z}$ 457.1466 [M+Na] ${ }^{+}$ (calcd for $\mathrm{C}_{22} \mathrm{H}_{26} \mathrm{NaO}_{9}, 457.1470$ ).

Coriandralpinin $\mathbf{H}(\mathbf{8})$ : light brown oil, $[\alpha]_{\mathrm{D}}^{20}+34.9(c$ $0.25, \mathrm{MeOH})$. UV (MeOH) $\lambda_{\max } \mathrm{nm}(\log \varepsilon): 206$ (3.92), 235 (3.10), 271 (2.31); ${ }^{1} \mathrm{H}$ and ${ }^{13} \mathrm{C}$ NMR data were depicted Tables 1 and 2. (+)-HRESIMS: $\mathrm{m} / z 487.1942$ $[\mathrm{M}+\mathrm{Na}]^{+}$(calcd for $\mathrm{C}_{24} \mathrm{H}_{32} \mathrm{NaO}_{9}, 487.1939$ ), $m / z, 951.3994$ $[2 \mathrm{M}+\mathrm{Na}]^{+}$(calcd for $\mathrm{C}_{48} \mathrm{H}_{64} \mathrm{NaO}_{18}, 951.3985$ ).

\subsection{Cell Viability Assay}

The murine macrophage RAW 264.7 cell line was obtained from Kunming Institute of Zoology, Chinese Academy of Sciences (Kunming, China). The cells were cultured in DMEM medium supplemented with $10 \%$ heated-inactivated fetal bovine serum in a $37{ }^{\circ} \mathrm{C}, 5 \% \mathrm{CO}_{2}$ incubator. Compounds 1-8, curcumin, and $t$-BHP were assessed for cytotoxicity against RAW 264.7 cells at various concentrations $(100,50,10$, and $2 \mu \mathrm{M})$ by MTT method as previously described [31].

\subsection{Cellular Antioxidant Activity Assay}

In the MTT cell viability assay, $50 \mu \mathrm{M}$ of $t$-BHP (SigmaAldrich, USA, TBH70X) treatment for $3 \mathrm{~h}$ provoked about $60 \%$ of cell death and this condition was selected for the subsequent experiments as reported [29, 30]. Briefly, RAW 
264.7 cells $\left(4 \times 10^{4}\right.$ cells/well $)$ were seeded into a black 96-well plate and allowed to growth for $24 \mathrm{~h}$, then treated with either compounds $(100,50,25,12.5$, and $6.25 \mu \mathrm{M})$ or the positive control curcumin $(20,10,5,2.5$, and $1.25 \mu \mathrm{M})$ for $24 \mathrm{~h}$. After stained with $20 \mu \mathrm{M}$ DCFH-DA (Sigma, USA) for $1 \mathrm{~h}$ in darkness, the cells were exposed to $50 \mu \mathrm{M}$ $t$-BHP for $1 \mathrm{~h}$ to induce ROS generation. The supernatants of cell cultures were measured for intracellular ROS levels using the fluorescence intensity at excitation wavelength of $485 \mathrm{~nm}$ and the emission wavelength of $530 \mathrm{~nm}$ by microplate reader (Tecan Group Ltd., Swizerland).

\subsection{Anti-Inflammatory Activity Evaluation}

The in vitro anti-inflammatory activity was evaluated by measuring the inhibitory effects of compounds on NO production in LPS-stimulated RAW 264.7 macrophages as previously described [32]. Briefly, the supernatants of cells were obtained as described above and RAW 264.7 cells were pretreated with different concentrations of compounds 1-8 $(50,25,12.5,6.25$, and $3.125 \mu \mathrm{M})$ at $37^{\circ} \mathrm{C}$ for $1 \mathrm{~h}$, followed by stimulated with LPS $(0.1 \mu \mathrm{g} / \mathrm{ml})$ for $24 \mathrm{~h}$. DMSO $(0.1 \%)$ and dexamethasone $(50,25,12.5,6.25$ and $3.125 \mu \mathrm{M})$ were used as vehicle and positive controls, respectively. The levels of NO were determined using commercial NO assay kit (Beyotime Institute of Biotechnology, China). $50 \mu \mathrm{L}$ of Griess reagent I and $50 \mu \mathrm{L}$ of Griess reagent II were added to $100 \mu \mathrm{L}$ of the supernatants of cells $\left(9 \times 10^{5} / \mathrm{mL}\right)$.

\subsection{Computational Methods}

Molecular Merck force field (MMFF) and DFT/TDDFT calculations were performed with Spartan'14 software package (Wavefunction Inc., Irvine, CA, USA) and Gaussian09 program package [33], respectively. The structures, $(1 S, 3 R, 5 S)-\mathbf{1},(1 S, 3 R, 5 R)-\mathbf{6},(1 S, 3 R, 5 R, 7 R)-\mathbf{8}$, and $(1 S, 3 R, 5 R, 7 S)-\mathbf{8}$, were applied to the theoretical calculations. MMFF conformational search generated low-energy conformers within a $10 \mathrm{kcal} / \mathrm{mol}$ energy window were subjected to geometry optimization using DFT method at the B3LYP/def2-SVP [34] level of theory with the solvent model PCM for $\mathrm{MeOH}$. Frequency calculations were run at the same level to verify that each optimized conformer was a true minimum and to estimate their relative thermal free energies $(\Delta G)$. The optimized minima (Table S1, Supplementary Material) within the relative energies of $4.0 \mathrm{kcal} /$ mol were subjected to the higher level of energy calculations at the M06-2X [35]/def2-TZVP [34] level with the solvent model SMD for $\mathrm{MeOH}$. The TDDFT calculations were performed using the hybrid PBE0 (PBE1PBE) [36, 37] and M06-2X functionals, and Ahlrichs' basis sets def2-SVP and TZVP [38] with the PCM for $\mathrm{MeOH}$. The number of excited states per each molecule was 42 for all compounds. The ECD spectra were generated by the program SpecDis [39] using a Gaussian band shape from rotational strengths. The final calculated spectra were generated by averaging calculated spectra of the low-energy conformers according to the Boltzmann weighting of each conformer in $\mathrm{MeOH}$ solution. The theoretical ECD spectra of $(1 R, 3 S, 5 R)-\mathbf{1},(1 R, 3 S, 5 S)-\mathbf{6},(1 R, 3 S, 5 S, 7 S)-\mathbf{8}$, and $(1 R, 3 S, 5 S, 7 R)-\mathbf{8}$, were obtained by mirror-inversion of the calculated spectra for $(1 S, 3 R, 5 S)-\mathbf{1},(1 S, 3 R, 5 R)-\mathbf{6}$, $(1 S, 3 R, 5 R, 7 R)-\mathbf{8}$, and $(1 S, 3 R, 6 R, 7 S)-\mathbf{8}$, respectively.

For calculations of the ${ }^{13} \mathrm{C}$ NMR shifts of $\mathbf{8}$, low-energy conformers of the stereoisomers, $(1 S, 3 R, 5 R, 7 R)-\mathbf{8}$ and $(1 S, 3 R, 5 R, 7 S)-\mathbf{8}$, obtained in above ECD simulations, were subjected to NMR calculations using the gauge including atomic orbitals (GIAO) method [40, 41, 42] at the mPW1PW91/6-311+G(d,p)/PCM level [43]. The unscaled chemical shifts $\left(\delta_{\mathrm{u}}\right)$ were computed using TMS as reference standard according to $\delta_{\mathrm{u}}=\sigma_{0}-\sigma^{\mathrm{x}}$ (where $\sigma^{\mathrm{x}}$ is the Boltzmann averaged shielding tensor and $\sigma_{0}$ is the shielding tensor of TMS computed at the same level employed for $\sigma^{\mathrm{x}}$ ). The Boltzmann averaging was done at $298.15 \mathrm{~K}$ using the relative energies obtained from the single-point NMR calculations [44, 45]. The goodness of fit between the predicted ${ }^{13} \mathrm{C}$ NMR data of the two stereoisomers and the experimental shifts of compound $\mathbf{8}$ were evaluated by the improved DP4 probability (DP4+) [44, 45].

Acknowledgements We are grateful to Mr. Yunfei Yuan, South China Botanical Garden, Chinese Academy of Sciences (CAS), for NMR spectroscopic measurements and Ms. Aijun Sun, South China Sea Institute of Oceanology, CAS, for HRESIMS measurements. We also gratefully acknowledge support from the Guangzhou Branch of the Supercomputing Center of CAS. This work was financially supported by NSFC Grants (Nos. 81172942 and 81872773 ).

\section{Compliance with Ethical Standards}

Conflict of interest The authors declare no competing financial interest.

Open Access This article is licensed under a Creative Commons Attribution 4.0 International License, which permits use, sharing, adaptation, distribution and reproduction in any medium or format, as long as you give appropriate credit to the original author(s) and the source, provide a link to the Creative Commons licence, and indicate if changes were made. The images or other third party material in this article are included in the article's Creative Commons licence, unless indicated otherwise in a credit line to the material. If material is not included in the article's Creative Commons licence and your intended use is not permitted by statutory regulation or exceeds the permitted use, you will need to obtain permission directly from the copyright holder. To view a copy of this licence, visit http://creativecommons.org/licenses/by/4.0/. 


\section{References}

1. A.M. Pisoschi, A. Pop, Eur. J. Med. Chem. 97, 55-74 (2015)

2. B.C. Dickinson, C.J. Chang, Nat. Chem. Biol. 7, 504-511 (2011)

3. A.S. Marchev, P.A. Dimitrova, A.J. Burns, R.V. Kostov, A.T. Dinkova-Kostova, M.I. Georgiev, Ann. N. Y. Acad. Sci. 1401, 114-135 (2017)

4. N. Braidy, M. Izadi, A. Sureda, N. Jonaidi-Jafari, A. Banki, S.F. Nabavi, S.M. Nabavi, J. Cell. Physiol. 233, 2705-2714 (2018)

5. S. Prasad, S.C. Gupta, A.K. Tyagi, Cancer Lett. 387, 95-105 (2017)

6. V. Rani, G. Deep, R.K. Singh, K. Palle, U.C. Yadav, Life Sci. 148, 183-193 (2016)

7. C. Calixto-Campos, T.T. Carvalho, M.S. Hohmann, F.A. PinhoRibeiro, V. Fattori, M.F. Manchope, A.C. Zarpelon, M.M. Baracat, S.R. Georgetti, R. Casagrande, J. Nat. Prod. 78, 1799-1808 (2015)

8. X. Hou, Q. Tong, W. Wang, C. Shi, W. Xiong, J. Chen, X. Liu, J. Fang, J. Nat. Prod. 78, 1689-1696 (2015)

9. L. Zhou, G.-D. Yao, X.-Y. Song, J. Wang, B. Lin, X.-B. Wang, X.-X. Huang, S.-J. Song, J. Agric. Food Chem. 66, 331-338 (2017)

10. Y.H. Seo, J.H. Jeon, M. Jeong, S.M. Ryu, W.K. Jeon, D.S. Jang, S.H. Shim, D. Lee, J.H. Choi, J. Lee, J. Nat. Prod. 81, 1598-1603 (2018)

11. K. Gao, D. Ma, Y. Cheng, X. Tian, Y. Lu, X. Du, H. Tang, J. Chen, J. Agric. Food Chem. 63, 1067-1075 (2015)

12. X.X. Huang, M. Bai, L. Zhou, L.L. Lou, Q.-B. Liu, Y. Zhang, L.Z. Li, S.J. Song, J. Agric. Food Chem. 63, 7252-7260 (2015)

13. A. Kumorkiewicz, E. Szneler, S. Wybraniec, J. Agric. Food Chem. 66, 12815-12826 (2018)

14. Y. Tang, Z.Z. Zhao, J.N. Yao, T. Feng, Z.H. Li, H.-P. Chen, J.K. Liu, J. Nat. Prod. 81, 2163-2168 (2018)

15. Q.Y. Bian, S.Y. Wang, L.J. Xu, C.O. Chan, D.K. Mok, S.B. Chen, J. Asian Nat. Prod. Res. 15, 1094-1099 (2013)

16. T.N. Ly, M. Shimoyamada, K. Kato, R. Yamauchi, J. Agric. Food Chem. 51, 4924-4929 (2003)

17. Y.J. Kuo, P.C. Hsiao, L.J. Zhang, M.D. Wu, Y.H. Liang, H.O. Ho, Y.H. Kuo, J. Nat. Prod. 72, 1097-1101 (2009)

18. R. Singh, P. Sharma, Toxicol. Int. 18, 124-129 (2011)

19. D. Liu, Y.W. Liu, F.Q. Guan, J.Y. Liang, Fitoterapia 96, 76-80 (2014)

20. N. An, Z.M. Zou, Z. Tian, X.Z. Luo, S.L. Yang, L.Z. Xu, Fitoterapia 79, 27-31 (2008)

21. H. Kikuzaki, N. Nakatani, Phytochemistry 43, 273-277 (1996)
22. M.A.M. Nawwar, A.M.A. Souleman, J. Buddrus, M. Linscheid, Phytochemistry 23, 2347-2349 (1984)

23. X.W. Yang, Y.M. Jiang, J.S. Li, Z.C. Lou, Zhong Cao Yao 27, 707-712 (1996)

24. J.Y. Si, D.H. Chen, Q. Chang, L.G. Shen, Z.Y. Zhu, Acta Botanica Sinica 36, 239-243 (1994)

25. H. Dong, Y.L. Gou, S.G. Cao, S.X. Chen, K.Y. Sim, S.H. Goh, R.M. Kini, Phytochemistry 50, 899-902 (1999)

26. J.T. Han, M.H. Bang, O.K. Chun, D.O. Kim, C.Y. Lee, N.L. Baek, Arch. Pharm. Res. 27, 390-395 (2004)

27. G. Goetz, A. Fkyerat, N. Métais, M. Kunz, R. Tabacchi, R. Pezet, V. Pont, Phytochemistry 52, 759-767 (1999)

28. D.J. Sun, L.J. Zhu, Y.Q. Zhao, Y.Q. Zhen, L. Zhang, C.C. Lin, L.X. Chen, Fitoterapia 142, 104490 (2020)

29. F. Cheng, Y. Chen, Z. Zhan, Y. Liu, P. Hu, H. Ren, H. Tang, M. Peng, Inflammation 41, 1-16 (2018)

30. Q.F. Tao, Y. Xu, R.Y.Y. Lam, B. Schneider, H. Dou, P.S. Leung, S.Y. Shi, C.X. Zhou, L.X. Yang, R.P. Zhang, Y.C. Xiao, X. Wu, J. Stöckigt, S. Zeng, C.H.K. Cheng, Y. Zhao, J. Nat. Prod. 71, 12-17 (2008)

31. J.F. Shi, P. Wu, Z.H. Jiang, X.Y. Wei, Eur. J. Med. Chem. 71, 219-228 (2014)

32. P. Wu, J. Xue, L. Yao, L. Xu, H. Li, X. Wei, Org. Lett. 17, 4922$4925(2015)$

33. Gaussian 09, revision D.01, Gaussian, Inc., Wallingford, CT 2010

34. F. Weigend, R. Ahlrichs, Phys. Chem. Chem. Phys. 7, 3297-3305 (2005)

35. Y. Zhao, D.G. Truhlar, Theor. Chem. Acc. 120, 215-241 (2008)

36. J.P. Perdew, K. Burke, M. Ernzerhof, Phys. Rev. Lett. 77, 3865 3868 (1996)

37. C. Adamo, V. Barone, J. Chem. Phys. 110, 6158-6170 (1999)

38. A. Schäfer, H. Horn, R. Ahlrichs, J. Chem. Phys. 97, 2571-2577 (1992)

39. T. Bruhn, A. Schaumlöffel, Y. Hemberger, G. Bringmann, Chirality 25, 243-249 (2013)

40. R. Ditchfield, J. Chem. Phys. 56, 5688-5691 (1972)

41. R. Ditchfield, Mol. Phys. 27, 789-807 (1974)

42. K. Wolinski, J.F. Hinton, P. Pulay, J. Am. Chem. Soc. 112, 82518260 (1990)

43. M.W. Lodewyk, C. Soldi, P.B. Jones, M.M. Olmstead, J. Rita, J.T. Shaw, D.J. Tantillo, J. Am. Chem. Soc. 134, 18550-18553 (2012)

44. S.G. Smith, J.M. Goodman, J. Am. Chem. Soc. 132, 12946-12959 (2010)

45. N.S. Grimblat, M.M. Zanardi, A.M. Sarotti, J. Org. Chem. 80, 12526-12534 (2015) 